\title{
Effects of ultraviolet-B radiation on simultaneous carbon and nitrogen transport rates by estuarine phytoplankton during a week-long mesocosm study
}

\author{
Laure Mousseau ${ }^{1, *}$, Michel Gosselin ${ }^{1}$, Maurice Levasseur ${ }^{2}$, Serge Demers ${ }^{1}$, \\ Juliette Fauchot ${ }^{1}$, Suzanne Roy ${ }^{1}$, Piedad Zulema Villegas ${ }^{1}$, Behzad Mostajir ${ }^{1}$ \\ ${ }^{1}$ Institut des sciences de la mer de Rimouski (ISMER), Université du Québec à Rimouski, 310 allée des Ursulines, \\ Rimouski, Québec G5L 3A1, Canada \\ ${ }^{2}$ Institut Maurice-Lamontagne, Ministère des Pêches et des Océans, CP 1000, Mont-Joli, Québec G5L 3Z4, Canada
}

\begin{abstract}
The effect of UV-B radiation on photosynthesis and nitrogen uptake by an estuarine phytoplankton community was investigated during a week-long experiment, conducted in 8 mesocosms under varying conditions of UV-B radiation: reduced UV-B, natural radiation, and 2 levels of enhanced UV-B. Twice a day, dissolved inorganic carbon $\left({ }^{13} \mathrm{C}\right)$ and total dissolved nitrogen $\left({ }^{15} \mathrm{~N}\right)$ transport rates were estimated simultaneously from in situ incubations. Irrespective of the treatment, phytoplankton biomass (chlorophyll a) and primary production increased over the first $3 \mathrm{~d}$. Subsequently, nitrate and silicate depletion resulted in a decrease in algal biomass and productivity. Enhanced UV-B radiation was deleterious to chlorophyll a specific transport rates of $\mathrm{C}$ and $\mathrm{N}$ when compared to reduced and natural UV-B. The C:N transport ratios, as well as the POC:PON ratios, were generally not affected by enhanced or reduced UV-B. In the enhanced UV-B treatments, carbon transport rates were often significantly higher in the afternoon than in the morning, suggesting that phytoplankton exposed to UV-B developed photoprotective mechanisms against UV radiation on a daily basis. A shift in the algal community assemblage from diatoms $(>10 \mu \mathrm{m})$ to small flagellates $(5-10 \mu \mathrm{m})$ was observed during the study. Small flagellates were less sensitive to the UV-B treatments than diatoms, whose abundance decreased under reduced and enhanced UV-B. Results from this study suggest that UV-B exposure on a daily basis could change the chlorophyll a specific transport rates of $C$ and $N$ and alter the structure of the phytoplankton community.
\end{abstract}

KEY WORDS: Mesocosms - Nitrogen transport - Photoinhibition - Photosynthesis - Phytoplankton · St. Lawrence Estuary · UV-B radiation

\section{INTRODUCTION}

The recent decline of the stratospheric ozone concentrations has resulted in a major increase in ultraviolet-B radiation (UV-B: $280-320 \mathrm{~nm}$ ) reaching the Earth's surface (Kerr \& McElroy 1993), causing concern about the influence of UV-B radiation on living organisms. The impact of such changes in ambient solar radiation on plank-

\footnotetext{
-Present address: Observatoire Océanologique, BP 28, 06230 Villefranche-sur-Mer, France. E-mail: mousseau@obs-vlfr.fr
}

tonic communities is poorly known, and furthermore, since these variations are occurring rapidly, little is known about the time scale that would be required to develop adaptive responses. Until recently, attention has focused mainly on the Antarctic ecosystems where the ozone hole, and hence the relative increase in UV-B radiation, has been most pronounced. However, several studies have shown that ozone depletion was also occurring in temperate and arctic latitudes, leading to a corresponding increase in UV-B radiation (Kerr \& McElroy 1993, Fioletov \& Evans 1997, Fioletov et al. 1997, Rex et al. 1997, Tarasick \& Fioletov 1997). 
In marine waters, UV-B radiation can penetrate down to $30 \mathrm{~m}$ and can potentially disturb several biological processes (Vincent \& Roy 1993, Goes et al. 1995). Phytoplankton, in particular, which depends on solar energy for growth and photosynthesis, could be affected by changes in ambient UV-B levels. It has already been shown that UV radiation can reduce phytoplankton growth (Jokiel \& York 1984) and photosynthesis (Smith et al. 1992, Goes et al. 1996, Helbling et al. 1996b, Furgal \& Smith 1997), change photosynthate allocation (Döhler 1989, Furgal et al. 1998, Smith et al. 1998), alter nitrogen metabolism (Döhler 1985, 1992, 1997, Behrenfeld et al. 1995, Döhler \& Buchmann 1995, Goes et al. 1995, Döhler \& Hagmeier 1997, Fauchot et al. 2000), modify biochemical composition (Döhler \& Biermann 1994, Goes et al. 1994), and ultimately alter phytoplankton community structure (Jokiel \& York 1984, Döhler \& Biermann 1987, Helbling et al. 1996a, Santas et al, 1998).

During photosynthesis, solar radiation is transformed into chemical energy (e.g. ATP) which is then made available to other metabolic processes (Falkowski \& Stone 1975, Turpin \& Bruce 1990). For this reason, a tight coupling exists between photosynthesis and nitrogen incorporation by phytoplankton (Döhler 1985, Turpin \& Bruce 1990, Behrenfeld et al. 1995, Goes et al. 1995). As already demonstrated, damaging effects of UV radiation on photosynthetic electron transport (Melis et al. 1992, Schofield et al. 1995, Nilawati et al. 1997) as well as on photosynthetic production of ATP (Vosjan et al. 1990) and NADPH could alter the amount of energy available for nitrogen metabolism (Döhler et al. 1987, Behrenfeld et al. 1995, Döhler \& Buchmann 1995). Recently, Goes et al. (1994, 1995, 1996) demonstrated that the inhibition of photosynthesis by UV-B is accompanied by changes in the biosynthesis rates and composition of several biochemical compounds (fatty acids, monosaccharides and amino acids) in phytoplankton. These changes may alter the nutritive value of phytoplankton for upper trophic level organisms.

In this study, we describe the effects of reduced and enhanced UV-B radiation on simultaneous carbon and total nitrogen transport rates by an assemblage of estuarine phytoplankton. For $7 \mathrm{~d}$, carbon and nitrogen transport rates were simultaneously measured twice a day (morning, A.M., and afternoon, P.M.) in order to evaluate short-term ( $<1$ d) UV damage (photoinhibition, depressed nitrogen transport) and long-term (>1 d) potential for repair in the phytoplankton community. It is hypothesized that the impact of UV-B radiation on total nitrogen uptake is closely linked to that of carbon uptake, i.e. a decrease in photosynthetic rates should result in a decrease in total nitrogen uptake.

\section{MATERIALS AND METHODS}

Experimental setup. Mesocosm experiments were conducted from 17 to 23 July 1996 at the Pointeau-Père aquaculture research station (University of Québec; $68.2^{\circ} \mathrm{W}, 48.35^{\circ} \mathrm{N}$ ). Four land-based stainless steel tanks (1.30 m diameter, $2.55 \mathrm{~m}$ depth; $3200 \mathrm{l}$ ) were each divided into 2 polyethylene mesocosms (1500 l) and filled on 16 July (from 18:00 to 23:00 h) with filtered $(240 \mu \mathrm{m})$ seawater (salinity of 24 ) from the Lower St. Lawrence Estuary. The temperature in each mesocosm was maintained close to in situ temperatures (between 8 and $10^{\circ} \mathrm{C}$ ) by circulating estuarine water within the tank double-wall. In order to maintain a homogeneous water mass, a complete turnover of each mesocosm volume was done in $1 \mathrm{~h}$ using Little Giant pumps. A constant water level in the mesocosms was maintained by adding seawater between the double-walled tank and mesocosm walls (not inside mesocosms) after each sampling.

In order to assess the effects of UV-B radiation on the planktonic community transferred to mesocosms, 4 experimental designs were set up with different UV-B exposures: natural solar radiation (NUV-B), reduced UV-B (WUV-B), low UV-B enhancement (LUV-B) and high UV-B enhancement (HUV-B). For the WUV-B treatment, the tanks were covered with a $0.13 \mathrm{~mm}$ Mylar D sheet which eliminates radiation between 280 and $312 \mathrm{~nm}$. This sheet cuts ca $91 \%$ of incident UV-B, $28 \%$ of incident ultraviolet-A radiation (UV-A, $320-400 \mathrm{~nm}$ ) and $13 \%$ of incident photosynthetically available radiation (PAR, 400 to $700 \mathrm{~nm}$ ) on a sunny summer day at noon (Nozais et al. 1999). Two or 3 UV-B lamps (model XX15B, Spectronics Corporation) were used for LUV-B and HUV-B treatments, respectively. To eliminate UV-C radiation $(<280 \mathrm{~nm})$, the emission spectrum from the lamps was filtered with an aged ( $1 \mathrm{~h}$ at $1 \mathrm{~cm}$ from the lamps) $0.13 \mathrm{~mm}$ cellulose acetate sheet (Cadillac Plastics) which was changed every day. Lamps were pre-burned for $100 \mathrm{~h}$ before the beginning of the experiment and were switched on $1 \mathrm{~h}$ before use each day in order to attain a constant emission spectrum and UV-B intensity during the experiment. The lamps, positioned $40 \mathrm{~cm}$ above the water surface, were switched on from 09:00 to $17: 30 \mathrm{~h}$ every day. Similar shading conditions were created over NUV-B, LUV-B and HUV-B tanks by using wooden lamp replicates (Belzile et al. 1998). No wooden lamp replicate was installed over the WUV-B mesocosms because the Mylar sheet was already reducing incident irradiance.

Vertical profiles of PAR and UV irradiance in the water column of each mesocosm were measured with a PUV-500 radiometer (Biospherical Instruments). This radiometer measures the cosine-corrected down- 
welling irradiance in the visible (PAR) and at 4 discrete wavebands in the UV range $(305,320,340$ and $380 \mathrm{~nm}$ ). The irradiance values measured at $305 \mathrm{~nm}$ were multiplied by 2.6 to offset the underestimation resulting from the lamp calibration method, as suggested by Kirk et al. (1994). UV enhancements provided by the lamps just below the water surface at 305 , 320,340 and $380 \mathrm{~nm}$ averaged 5.62, 4.97, 2.08 and $0.09 \mu \mathrm{W} \mathrm{cm} \mathrm{cm}^{-2} \mathrm{~nm}^{-1}$ for LUV-B and $8.22,7.28,3.04$ and $0.13 \mu \mathrm{W} \mathrm{cm} \mathrm{cm}^{-2} \mathrm{~nm}^{-1}$ for HUV-B (Belzile et al. 1998). Incident irradiance (PAR, UV-A, UV-B) was recorded every $1 \mathrm{~min}$ with an IL-1700 radiometer (International Light) equipped with SUD033/PAR/QNSD1/W (PAR), SUD033/UV-A/W (UV-A) and SUD240/SPS300/T/W (UV-B) broadband and flat sensors. Only ca $40 \%$ of the incident irradiance reached the surface of the mesocosms, due to the shading created by the tank walls, the lamps and the lamp dummies. UV-B radiation was rapidly attenuated within the mesocosms (mean depths of $1 \%$ surface irradiance at $305,320,340$ and $380 \mathrm{~nm}$ were $0.9,0.93,1.1$ and $1.6 \mathrm{~m}$, respectively) while $4 \%$ of the surface PAR reached the bottom of the tanks. The NUV-B treatment served as the control. Additional details on the experimental setup and light measurements are given in Belzile et al. (1998).

Sampling and biochemical analyses. Twice a day (09:00 and 13:00 h), water was sampled $15 \mathrm{~cm}$ below the water surface to estimate nutrient concentrations $\left(\mathrm{NO}_{3}+\mathrm{NO}_{2}, \mathrm{NO}_{2}, \mathrm{NH}_{4}\right.$, urea, $\left.\mathrm{Si}(\mathrm{OH})_{4}\right)$ and carbon and nitrogen transport rates. Water for nutrient analysis was filtered onto pre-combusted Whatman GF/F filters. Analyses were performed either immediately for ammonium using the method of Solórzano (1969) described in Parsons et al. (1984), or within 1 mo on the frozen filtrate with a Perstorp FS III Autoanalyzer (Alpkem, O.I. Analytical) for nitrate, nitrite and silicate and a Technicon Autoanalyzer for urea (Price \& Harrison 1987).

Carbon and nitrogen uptake rates were estimated using the tracer method of Dugdale \& Wilkerson (1986). For each sampling time, 3 polyethylene bags (Whirlpak) containing $250 \mathrm{mI}$ water were inoculated with trace additions of both ${ }^{13} \mathrm{C}\left(\mathrm{NaH}^{13} \mathrm{CO}_{3}\right)$ and ${ }^{15} \mathrm{~N}$ isotopes $\left(\mathrm{K}^{15} \mathrm{NO}_{3},{ }^{15} \mathrm{~N}\right.$-urea or $\left.\left({ }^{15} \mathrm{NH}_{4}\right)_{2} \mathrm{SO}_{4}\right)$. Final concentrations were $0.1 \mathrm{mM}\left({ }^{13} \mathrm{C}\right), 0.1 \mu \mathrm{M}\left({ }^{15} \mathrm{NO}_{3}\right.$ or $\left.{ }^{15} \mathrm{NH}_{4}\right)$ and $0.05 \mu \mathrm{M}\left({ }^{15} \mathrm{~N}\right.$-urea). Samples were then incubated in the middle of the corresponding mesocosm, just below the water surface. After a $4 \mathrm{~h}$ incubation, each sample was filtered on a precombusted Whatman $\mathrm{GF} / \mathrm{F}$ filter. Analyses were performed on desiccated filters $\left(24 \mathrm{~h}\right.$ at $\left.60^{\circ} \mathrm{C}\right)$ with a tracermass spectrometer (Europa Scientific) which measures the abundance of ${ }^{13} \mathrm{C}$ and ${ }^{15} \mathrm{~N}$, and the particulate organic carbon (POC) and nitrogen (PON). Carbon and nitrogen specific transport rates were calculated according to Eq. (2) in
Dugdale \& Wilkerson (1986) using a concentration of the laben (in atom \%) in the particulate fraction at time 0 of $1.11 \%$ for ${ }^{13} \mathrm{C}$ and $0.365 \%$ for ${ }^{15} \mathrm{~N}$. They were multiplied by POC or PON concentration to obtain carbon and nitrogen transport rates. The temporal variations of nitrate, ammonium and urea uptake rates are described in detail in Fauchot et al. (2000). In the present study, nitrate, ammonium and urea transport rates were summed to obtain total nitrogen transport rates. On the afternoon of Day 3 , the ${ }^{13} \mathrm{C}$ concentration added to the samples was uncertain and the absolute ${ }^{13} \mathrm{C}$ transport rate was not reliable. However, as this uncertainty was identical in all mesocosms, the relative transport rate could still be computed.

Water for chlorophyll a (chl a) determination was sampled 5 or 6 times a day $(09: 00,13: 00,17: 00,21: 00$, $01: 00$, and 5:00 h) for the first $4 \mathrm{~d}$, then 3 times a day thereafter $(09: 00,13: 00$ and 17:00 h). Samples were filtered onto Whatman GF/F filters which were kept frozen until $24 \mathrm{~h}$ extraction in $90 \%$ acetone at $4^{\circ} \mathrm{C}$. Concentrations were then determined fluorometrically (Parsons et al. 1984). Enumeration and identification of phytoplankton cells $>3 \mu \mathrm{m}$ were made on samples collected at 09:00 h on Days 1, 2, 4, 5 and 7 (Villegas 1999) using the Utermöhl technique (Lund et al. 1958). Samples were kept in acidic Lugol (Throndsen 1978) until analysis.

Statistical procedure. To compare the biological effects of UV-B radiation, 1-way analyses of variance (ANOVA) were performed for each sampling time with UV-B treatment as the grouping factor. A multiple comparison test of means (Least Significant Difference test) was used when significant differences were found between treatments ( $\operatorname{Zar}$ 1984). This test identifies which treatment differs significantly among the 4 experimental conditions.

\section{RESULTS}

\section{Light measurements}

Total daily incident irradiance ranged from 7.1 to $49 \mathrm{E}$ $\mathrm{m}^{-2}$, with minimal values between Days 3 and 5 due to overcast skies (Fig. 1a). Daily incident values of UV-B, UV-A and PAR varied from 6 to $34 \mathrm{~kJ} \mathrm{~m}^{-2}, 168$ to $928 \mathrm{~kJ} \mathrm{~m}^{-2}$ and 6.5 to $46 \mathrm{E} \mathrm{m}^{-2}$, respectively. Under cloudy skies, the proportion of incident UV-A relative to the total incident irradiance increased while the relative value of incident UV-B was less affected by the cloud cover (Fig. 1b). During the overcast period, the ratio of total ultraviolet radiation (UV-A + UV-B) to total incident irradiance was more than $7 \%$. It is also worth noting that the 2 enhanced UV-B mesocosms received a higher proportion of UV-B radiation (averaged over the 


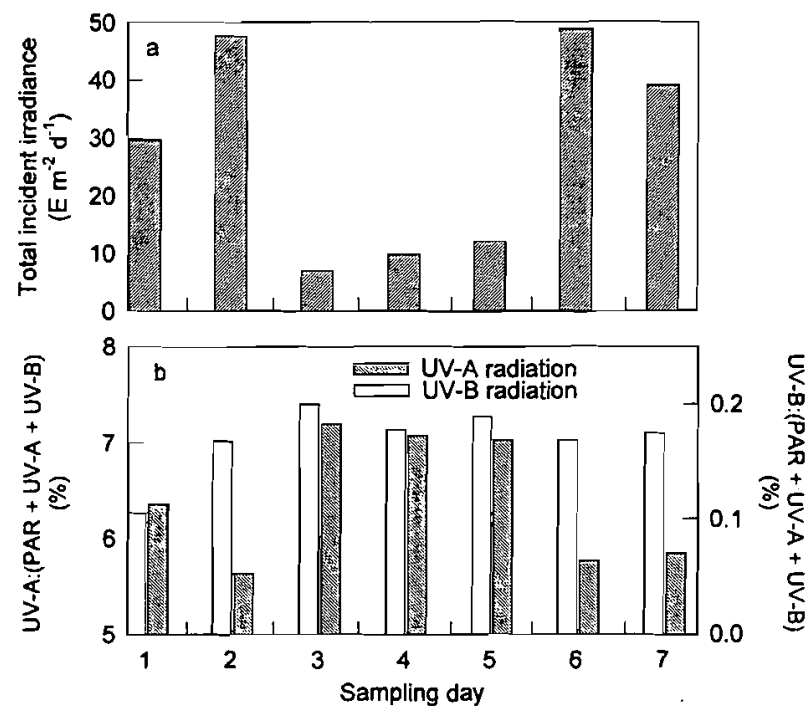

Fig. 1. Temporal variations of (a) total daily incident radiation (PAR + UV-A + UV-B) and (b) the ratios of daily incident UV-A (left scale) and UV-B (right scale) to total daily incident radiation. Incident irradiance was measured with an IL-1700 radiometer and ratios were calculated from data transformed to $\mathrm{E} \mathrm{m}^{-2} \mathrm{~d}^{-1}$

water column) during the overcast period $(>50 \%)$ than during the sunny period $(<20 \%)$ as the UV-B provided by the lamps was constant throughout the entire experiment, independent of natural radiation.

\section{Nutrients, chlorophyll $a$ and phytoplankton composition}

Since no effect of the UV-B treatments was apparent on ambient inorganic and organic nitrogen concentrations, a daily average for all tanks was computed. Nitrate concentrations decreased abruptly during the first $3 \mathrm{~d}$ of the experiment and then remained nearly undetectable thereafter (Fig. 2a). The pattern for ambient ammonium concentrations in contrast showed no definite trend and varied between 0.1 and $0.3 \mu \mathrm{M}$ (Fig. 2b). Urea concentrations decreased from $0.8 \mu \mathrm{M}$ to $0.4 \mu \mathrm{M}$ throughout the experiment with slightly higher values on Days 4 and 5 (Fig. 2c). Silicate concentrations decreased from $10 \mu \mathrm{M}$ on Day 1 to ca $1 \mu \mathrm{M}$ on Day 4 in all treatments (Fig. 2d). These concentrations continued to decrease in the NUV-B, WUV-B and LUV-B treatments but remained more or less constant in the HUV-B mesocosms. During the last $3 \mathrm{~d}$ of the experiment, the concentrations of silicate were significantly $(p<0.05)$ higher in the HUV-B mesocosms than in the NUV-B mesocosms (Fig. 2d).

From Days 1 to 3 , chl a biomass increased from ca $5 \mu \mathrm{g} \mathrm{l}^{-1}$ to ca $19 \mathrm{\mu g} \mathrm{l}^{-1}$ in all treatments (Fig. 3). Algal
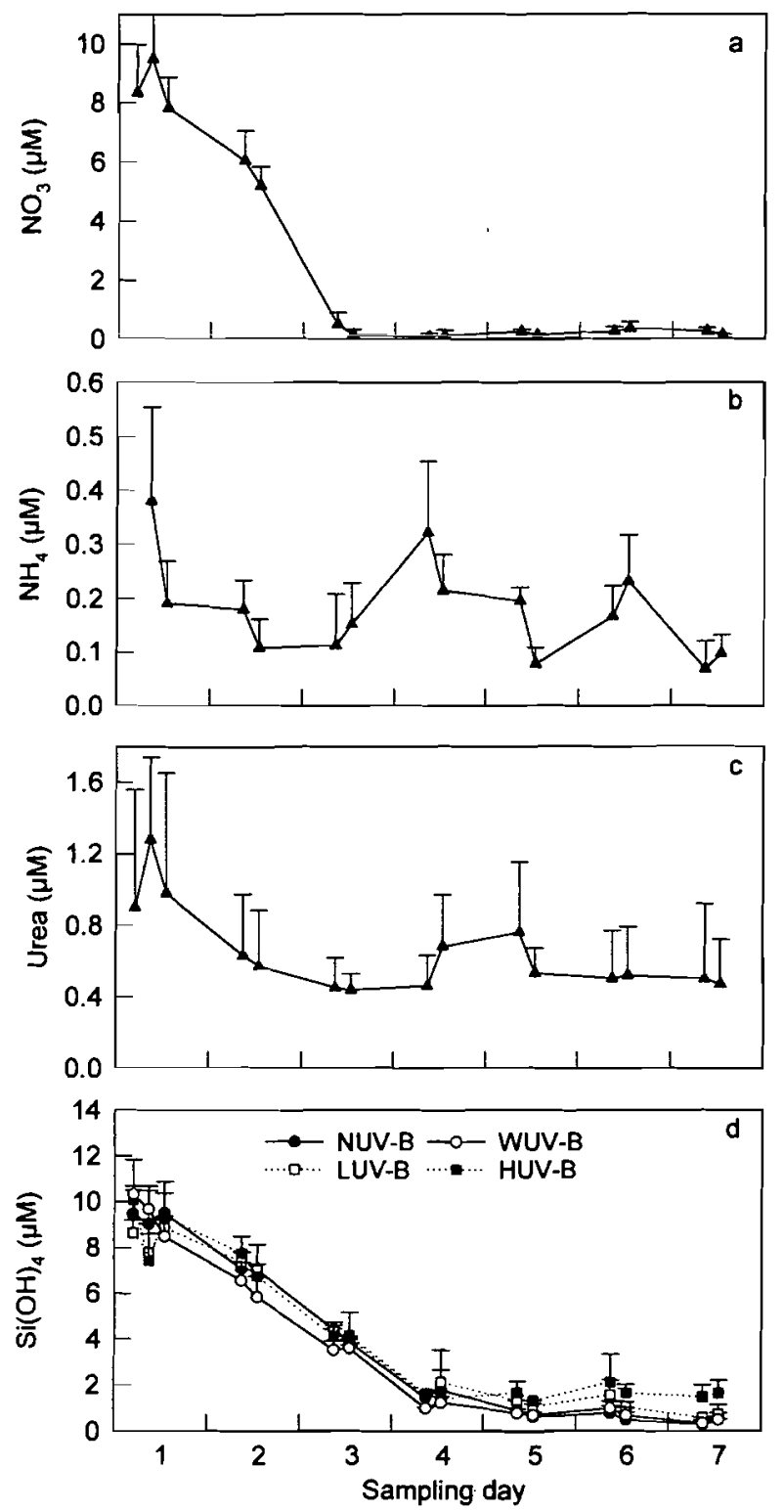

Fig. 2. Temporal variations in (a) nitrate, (b) ammonium, (c) urea and (d) silicate concentrations. Averages between the 8 mesocosms are computed for nitrogen nutrients while silicate concentrations are described for each tank. Average and standard deviation are shown

biomass started to decrease at the end of Day 4 reaching ca $12 \mu \mathrm{g} \mathrm{l}^{-1}$ at the end of the experiment. From Days 5 to 7 , phytoplankton biomass seemed to be more affected by reduced UV-B than by enhanced or natural UV-B. During the last $2 \mathrm{~d}$, chl a biomass was significantly $(\mathrm{p}<0.05)$ lower under reduced UV-B treatment than that under natural or enhanced treatments.

Phytoplankton including diatoms (mainly $10_{-15 \mu \mathrm{m}}$ Chaetoceros spp. and 13-18 $\mu \mathrm{m}$ Thalassiosira spp.), dinoflagellates (mainly 8-10 $\mu \mathrm{m}$ Katodinium spp., 
10-12 $\mu \mathrm{m}$ Heterocapsa spp. and 5-15 $\mu \mathrm{m}$ Prorocentrum spp.) and flagellates (mainly the 5.5-8.0 $\mu \mathrm{m}$ cryptophyte Plagioselmis spp. and the 6.0-9.0 $\mu \mathrm{m}$ prymnesiophyte Prymnesium spp.) started to increase after Day 2 in the 4 treatments (Fig. 4). Under enhanced and natural UV-B radiation, diatom abundances increased from $0.5 \times 10^{6}$ to ca $3.4 \times 10^{6}$ cells $\mathrm{l}^{-1}$ during the first $4 \mathrm{~d}$. On Day 5, their abundances under LUV-B $\left(2.4 \times 10^{6}\right.$ cells $\left.\mathrm{l}^{-1}\right)$ and HUV-B $(1.7 \times$

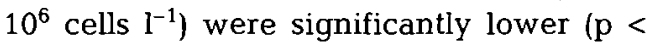
0.05 ) than under natural or reduced UV-B $\left(3.4 \times 10^{6}\right.$ and $4.2 \times 10^{6}$ cells $\mathrm{l}^{-1}$, respectively). At the end of the experiment, diatoms in the WUV-B, LUV-B and HUV-B treatments were significantly lower in abundance $(\mathrm{p}<$ 0.05 ) than under natural conditions (Fig. 4a). Dinoflagellates, the less abundant group, ranged from $0.1 \times 10^{6}$ cells $\mathrm{l}^{-1}$ on Day 1 to ca $0.9 \times$ $10^{6}$ cells $^{-1}$ on Day 4 , and then remained relatively constant until the end of the experiment (Fig. 4b). The abundance of flagellates increased continuously from ca $0.38 \times 10^{6}$ cells $^{-1}$ on Day 1 to $5 \times 10^{6}$ cells $^{-1}$ on Day 7 in all the mesocosms (Fig. 4c). Throughout the experiment, no statistically significant $(p<0.05)$ effect of UV-B treatments was observed on dinoflagellate and flagellate abundances. Under enhanced UV-B, the phytoplankton assemblage was dominated by diatoms ( $>55 \%$ of the total abundance) during the first $4 \mathrm{~d}$ and by naked flagellates and dinoflagellates ( $>63 \%$ of the total abundance) for the remainder of the experiment. This change in species composition was not distinguishable in the mesocosm under natural UV-B radiation, where diatoms and flagellates represented an equal proportion (ca $50 \%$ of the total abundance) of the phytoplankton assemblage during the whole experiment.

\section{Temporal variations of carbon transport rates}

The overall pattern of ${ }^{13} \mathrm{C}$ transport rates (Fig. 5a) was almost similar for the 4 treatments, with increasing values from Day 1 (ca $30 \mu \mathrm{g} \mathrm{Cl}^{-1} \mathrm{~h}^{-1}$ ) to attain a maximum value on Day 4 (ca $80 \mu \mathrm{g} \mathrm{C} \mathrm{l}^{-1} \mathrm{~h}^{-1}$ ) and then, rapidly decreasing towards the end of the experiment to values ca $15 \mu \mathrm{g} \mathrm{Cl}^{-1} \mathrm{~h}^{-1}$. From Days 1 to 4 , differences between the treatments were small, except on Day 3 A.M., when rates in the HUV-B treatment were significantly $(p<0.05)$ lower than the other treatments. From Day 4 onwards, neither enhanced nor reduced UV-B radiation treatments had a deleterious effect on ${ }^{13} \mathrm{C}$ transport rates, except on Day 5 when enhanced UV-B treatments significantly $(p<0.05)$ reduced uptake rates as compared to NUV-B conditions. On

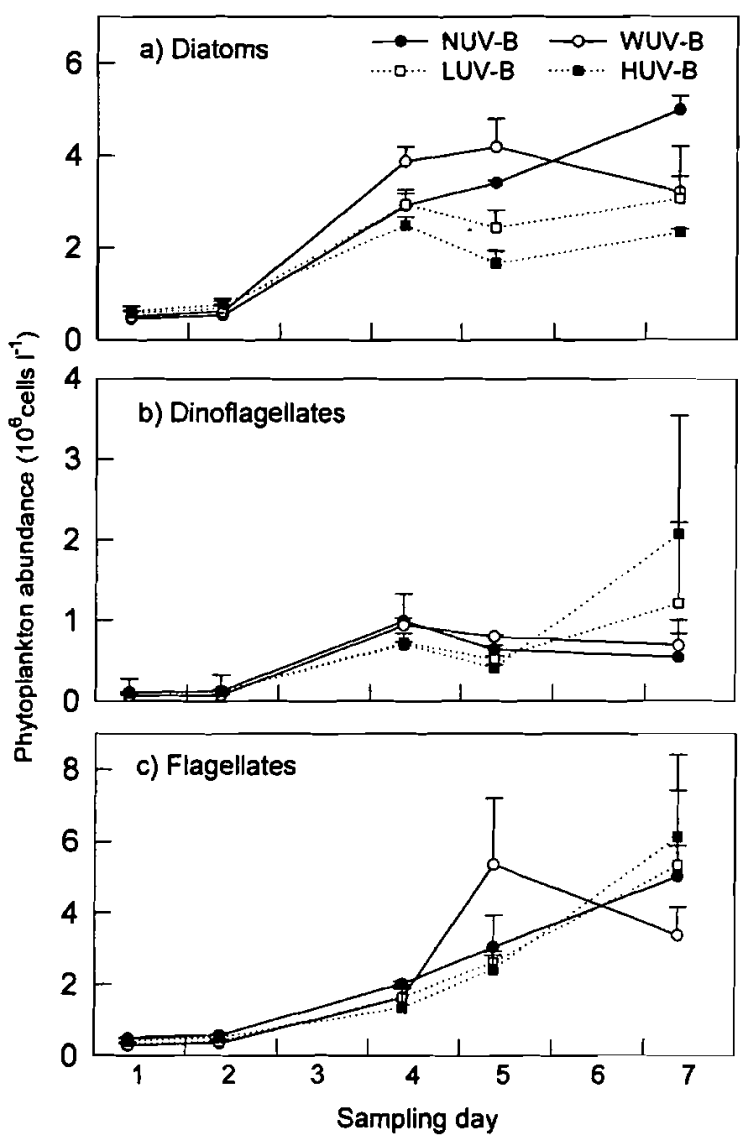

Fig. 4. Temporal variations in the abundances of (a) diatoms, (b) dinoflagellates, and (c) naked flagellates within the 4 UV-B treatments on Days 1, 2, 4, 5 and 7 . Average and standard deviation are shown

Days 2, 6 and 7, transport rates estimated in the afternoon were slightly higher than those in the morning, especially within the LUV-B and HUV-B samples. 

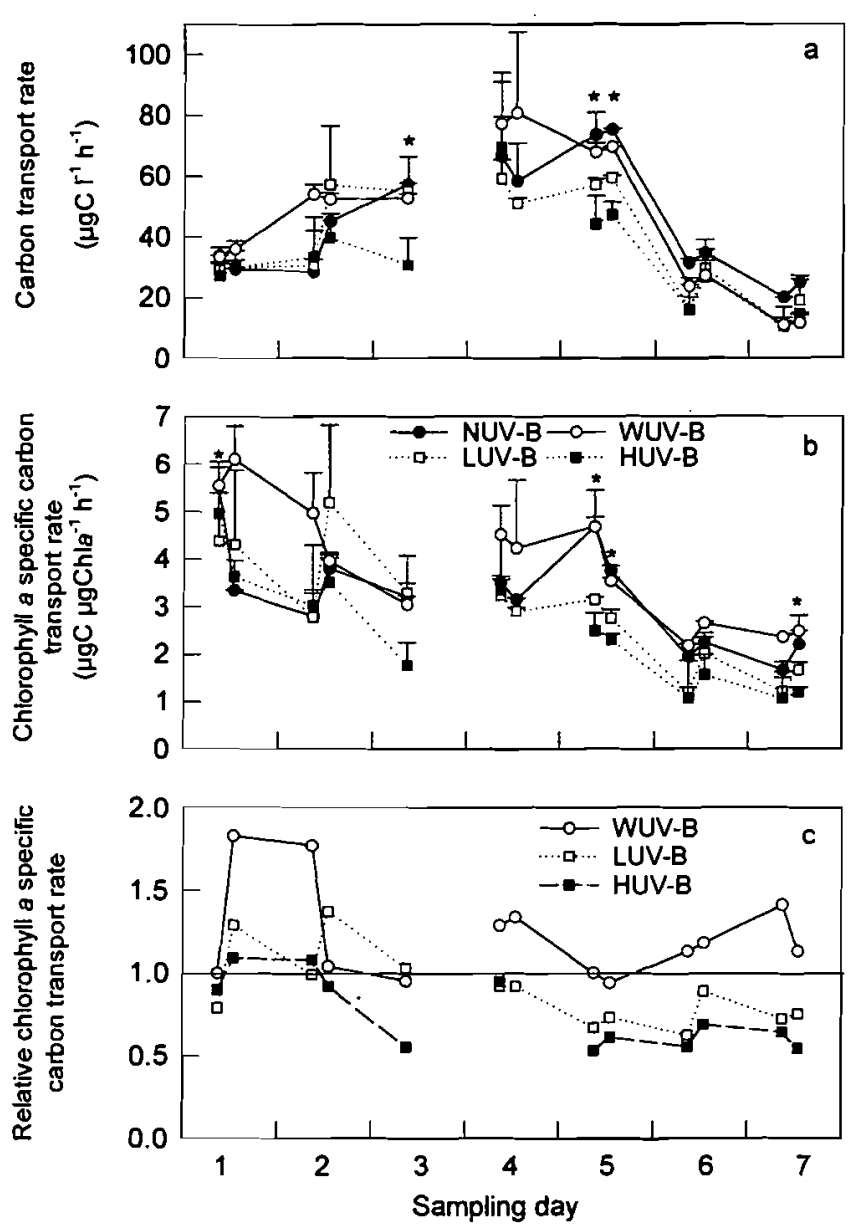

Fig. 5. Temporal variations of (a) carbon transport rate, (b) chl a specific carbon transport rate within the 4 UV-B treatments, and (c) relative chl $a$ specific carbon transport rate calculated as the ratio of treatment to natural conditions as control. Average and standard deviation are shown. Differences between treatments are statistically significant $(p<0.05)$

In order to estimate the potential ability of a given phytoplankton biomass to fix dissolved inorganic carbon, the chl a specific carbon transport rate was calculated as the ratio of the carbon transport rate per unit of $\mathrm{chl}$ a. This ratio remained close to $3.5 \mu \mathrm{g} \mathrm{C} \mu \mathrm{g}$ chl $a^{-1} h^{-1}$ for the first $5 \mathrm{~d}$ of the experiment except in the WUV-B mesocosms where values ranged between 5 and $6 \mu \mathrm{g} \mathrm{C} \mu \mathrm{g} \mathrm{chl} a^{-1} \mathrm{~h}^{-1}$ on Days 1 and 2 (Fig. $5 \mathrm{~b}$ ). Afterwards, the ratio decreased to ca $3 \mu \mathrm{g} \mathrm{C} \mu \mathrm{g}$ chl $a^{-1} \mathrm{~h}^{-1}$ in the NUV-B and WUV-B treatments and to ca $2 \mu \mathrm{g} \mathrm{C} \mu \mathrm{g} \mathrm{chl} a^{-1} \mathrm{~h}^{-1}$ in the LUV-B and HUV-B treatments (Fig. 5b). The deleterious effect of enhanced UV-B was clearly visible on Days 5 and 7 , when rates in the LUV-B and HUV-B treatments were significantly $(p<0.05)$ lower than in the other treatments.

The relative chl a specific carbon transport rates with respect to the NUV-B treatment (control) are presented in Fig. 5c. Ratio $>1$ indicates that photosynthesis was stimulated by the UV-B treatment whereas a ratio $<1$ indicates that photoinhibition occurred. Values were generally $>1$ for the WUV-B treatment while those for enhanced UV-B treatments remained below 1 after Day 2 A.M. in the HUV-B treatment, and after Day 3 P.M. in the LUV-B treatment (Fig. 5c).

\section{Temporal variations of total nitrogen transport rates}

In all treatments, total ${ }^{15} \mathrm{~N}$ transport rates peaked on Day 2 P.M., except for WUV-B, and then decreased to values similar to those measured on Day 1 (Fig. 6a). Under HUV-B, ${ }^{15} \mathrm{~N}$ transport rates were significantly lower $(p<0.05)$ than the other treatments on Days 1, 3 A.M., 4 A.M., 5, 6 P.M. and 7. In the LUV-B mesocosms, ${ }^{15} \mathrm{~N}$ transport rates on Days 4 A.M., 5 P.M., 6 P.M. and 7 A.M. were also significantly lower $(p<0.05)$ than under NUV-B and WUV-B treatments. As compared to natural radiation, reducing UV-B significantly stimulated $(p<0.05)$ nitrogen metabolism on the morning of Days 2,5 and 7 .

Chl a specific nitrogen transport rates (nitrogen uptake per unit of chl a) varied from 0.01 to $1.3 \mu \mathrm{g} \mathrm{N} \mu \mathrm{g}$ chl $a^{-1} \mathrm{~h}^{-1}$ (Fig. 6b). On Days 1, 2, 6 P.M. and 7, the chl a specific nitrogen transport rates under reduced UV-B were significantly $(p<0.05)$ higher than those measured in the other treatments.

Relative to the NUV-B sample, chl a specific nitrogen transport rates were generally higher (ratio $>1$ ) in the WUV-B treatment and were lower (ratio < 1) for HUV-B treated samples (Fig. 6c). Relative values for the LUV-B treatment varied between 0.5 and 1.3 , ranging between the values observed in the WUV-B and HUV-B treatments.

\section{Percent change in carbon and nitrogen transport rates}

To estimate the effect of UV-B treatments on carbon and nitrogen transport rates, we compared transport rates $(\rho)$ under reduced and enhanced UV-B against those under natural UV-B (control) by calculating the $\left[\rho_{\text {treatment }}-\rho_{\text {control }} / / \rho_{\text {control }}\right]$ ratio. The percent change for carbon transport rates generally decreased throughout the experiment in each treatment, the variations depending on the treatment and the time of sampling (Fig. $7 a, b$ ). In the morning samples, a negative effect appeared from Day 4 to the end of the experiment in all treatments whereas, in the afternoon period, it started on Day 1 under HUV-B treatment and on Day 3 

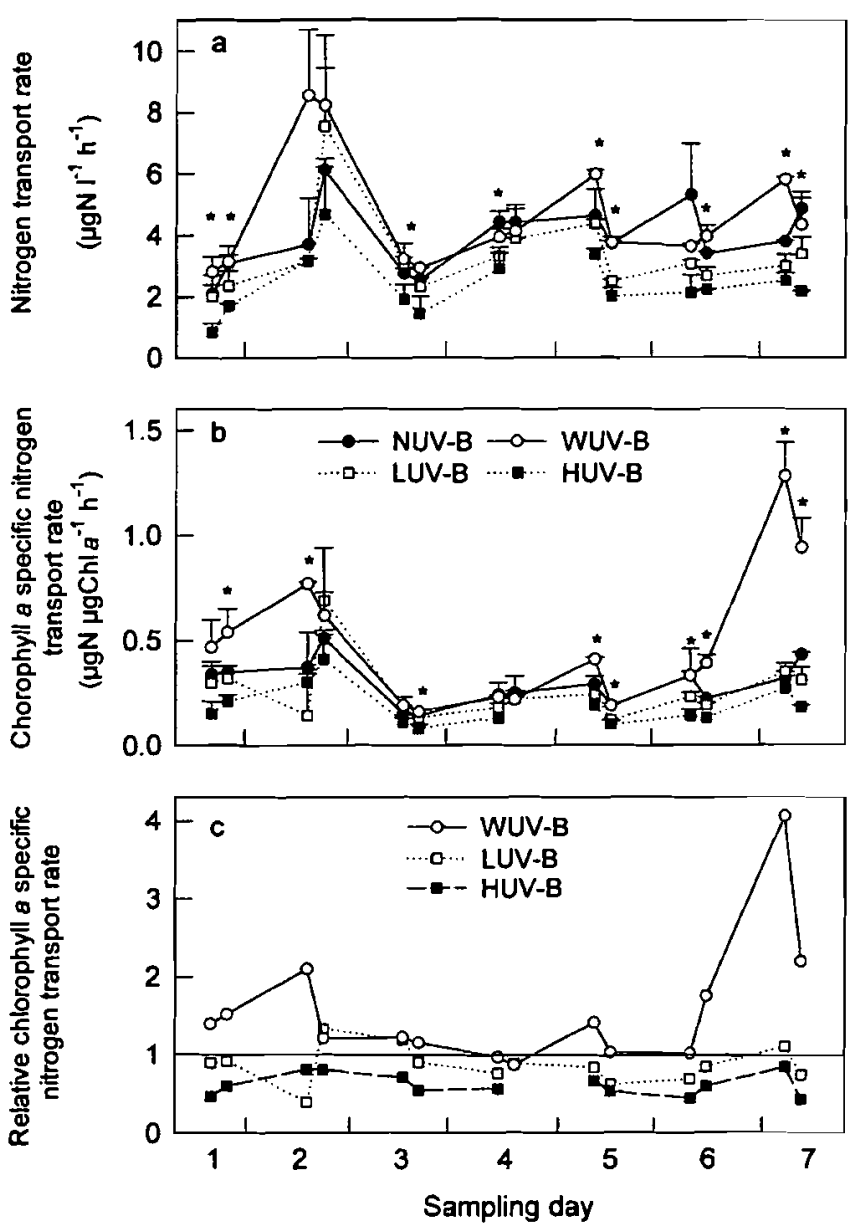

Fig. 6. Temporal variations of (a) total nitrogen transport rate, (b) chl a specific total nitrogen transport rate within the 4 UV-B treatments, and (c) relative chl a specific nitrogen transport rate calculated as the ratio of treatment to natural conditions as control. Average and standard deviation are shown. - Differences between treatments are statistically significant $(p<0.05)$

in the LUV-B mesocosms. For total mitrogen transport rates, negative percent changes were observed from the beginning to the end of the experiment in the HUV-B treatment while the values remained negative after Day 3 A.M. in the LUV-B treatment (Fig. $7 \mathrm{c}, \mathrm{d}$ ). The deleterious effects of UV-B on carbon and nitrogen production were again more obvious as the absolute percent change in carbon and nitrogen transport rates in the HUV-B treatment was most often higher than that in the LUV-B treatment. Reducing UV-B did not have the same impact on the transport rates of carbon as on those of nitrogen. In the WUV-B mesocosms, negative percent changes for carbon were observed from Day 5 onwards while no distinct trend for total nitrogen transport rates was detected, irrespective of the time of day (Fig. 7).

\section{Temporal variations in the ratios of carbon to nitrogen transport rates and of POC to PON}

Similar trends were observed between the control and treatments for the ratios of carbon to nitrogen transport rates and of POC to PON (Fig. 8a, b). During the first $5 \mathrm{~d}$ of the experiment, the ratios of carbon to nitrogen transport rates varied between ca 7 and ca $40 \mu \mathrm{g}$-at $\mathrm{C}\left(\mu \mathrm{g}\right.$-at $\left.\mathrm{N}^{-1}\right)$, with maximum values on Days 1 A.M., 3 A.M., 4 A.M. and 5 P.M. (Fig. 8a). Thereafter, they decreased to reach ca $2 \mu \mathrm{g}$-at $\mathrm{C} \mu \mathrm{g}$-at $\mathrm{N}^{-1}$ on Day 7 . In the HUV-B and WUV-B treatments, the C:N uptake ratio was significantly $(p<0.05)$ different from the other treatments on Days 1 A.M. and 7 P.M., respectively.

POC:PON atomic ratios decreased from ca 7 on Day 1 to ca 5 on the afternoon of Day 3. Then, values started to increase up to ca 8.5 on Day 7 (Fig. 8b). During the first $4 \mathrm{~d}$ of the experiment, there was no significant difference in the POC:PON ratio between treatments. However later on, this ratio was slightly but significantly $(p<0.05)$ lower in the HUV-B (Days 5, 6 A.M. and 7 A.M.), LUV-B (Day 7 A.M.) and WUV-B (Day 7) treatments than under NUV-B experimental conditions.

\section{DISCUSSION}

\section{Experimental conditions}

UV-B radiation reaching the Earth's surface is considered a natural stress for aquatic organisms (Behrenfeld et al. 1994). This study provides the first results of the effects of UV-B radiation on the simultaneous transport rates of dissolved inorganic carbon and total dissolved nitrogen (i.e. nitrate + ammonium + urea) by phytoplankton estimated with stable isotopes $\left({ }^{13} \mathrm{C}\right.$ and ${ }^{15} \mathrm{~N}$ ). This study also represents the first such attempt on natural phytoplankton communities, as opposed to those conducted with laboratory cultures under totally artificial illumination conditions. In our study, a natural planktonic community, maintained in large volume mesocosms filled with water from the St. Lawrence Estuary, was subjected to different UV-B radiation regimes. This setup helped overcome constraints induced by laboratory studies (e.g., small volumes and time scales, culture media, artificial solar radiation). Consequently, the results of the present study are expected to more closely resemble field conditions.

Light attenuation in the water column of the mesocosm adequately reproduced that observed in the estuarine water column. In July, $1 \%$ of the surface PAR reached a depth of ca $5 \mathrm{~m}$ in the St. Lawrence Estuary (Levasseur et al. 1984) whereas in our experiment, the 


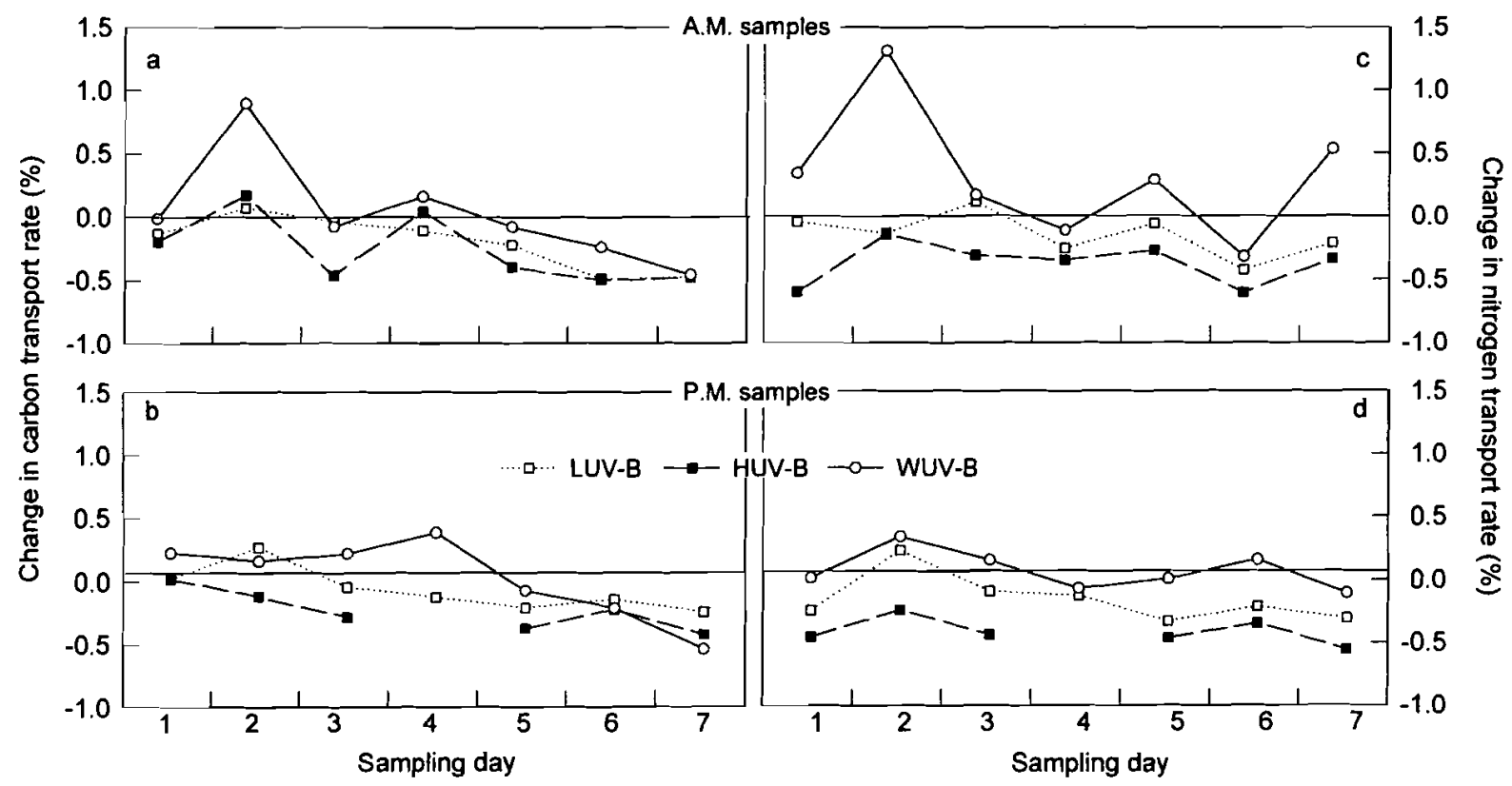

Fig. 7. Temporal variations of percent change of carbon $(a, b)$ and total nitrogen $(c, d)$ transport rate $\left[\left(\rho_{\text {treatment }}-\rho_{\text {control }}\right) / \rho_{\text {control }}\right]$ in morning and afternoon samples of each UV-B treatment
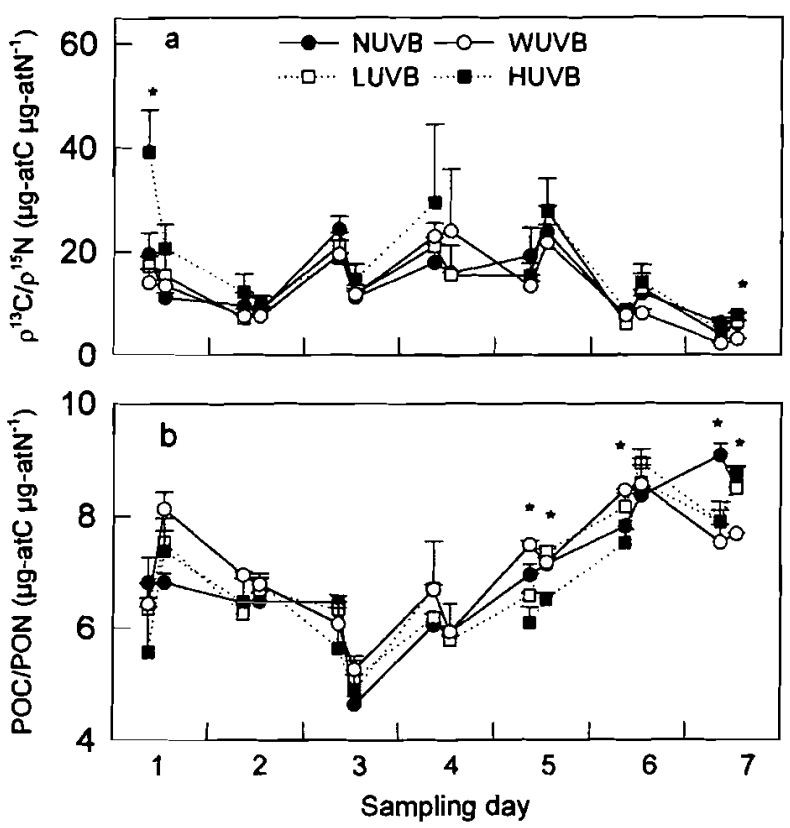

Fig. 8. Temporal variations of the ratios of (a) carbon to nitrogen transport rate and (b) particulate organic carbon to particulate organic nitrogen. Average and standard deviation are shown. "Differences between treatments are statistically significant $(\mathrm{p}<0.05)$

bottom of the mesocosm received $4 \%$ of incident PAR, the $1 \%$ depth being estimated at ca $3.1 \mathrm{~m}$ (Belzile et al. 1998). Attenuation of UV-B radiation in the mesocosms occurred rapidly, with $1 \%$ depth at ca $1 \mathrm{~m}$. In the enhanced treatments, UV-B radiation levels were somewhat higher than those associated with the ozone depletion over Antarctica (see Belzile et al. 1998, Mostajir et al. 1999b).

\section{Nutrients and phytoplankton composition}

Summer growth of phytoplankton takes place from June to September in the St. Lawrence Estuary, with maximal values of algal biomass and primary production generally in July (Levasseur et al. 1984, SimeNgando et al. 1995, Roy et al. 1996). Diatom growth at this time of the year is sustained by the high concentrations of nitrate and silicate. With the exhaustion of nitrate and silicate in the euphotic layer, diatom numbers decrease and flagellates become the dominant algal group (Levasseur et al. 1984). In all treatments examined in this study, changes in phytoplankton community structure and ambient nutrient concentrations did not differ from this general trend (Figs. $2 \& 4$ ). However, the response of the algal community (in terms of cell numbers) differed according to the treatment. From Days 5 to 7 , reduced UV-B affected chl a biomass while enhanced UV-B influenced phytoplankton productivity, abundance and species composition (Figs. 3, 4 \& 5a). At the end of the experiment, diatom $(>10 \mu \mathrm{m})$ numbers were lower under reduced and enhanced UV-B relative to natural conditions while the abundances of dinoflagellates $(5-15 \mu \mathrm{m})$ and naked flagellates $(5-10 \mu \mathrm{m})$ were not affected by the UV-B 
treatments. Since nitrate, ammonium and urea concentrations were similar in all treatments, these changes were not induced by nitrogen nutrients (Fig. 2a-c). Hence, we can reasonably postulate that these effects on community structure of phytoplankton were directly induced by UV-B or indirectly via predation (Mostajir et al. 1999a) and not by a bottom-up control by nutrients (sensu McQueen et al. 1986). Thus, in the HUV-B treatment, where the lowest diatom abundance was reached in spite of silicate availability, the stress induced by UV-B radiation on diatom growth appears to have been strong enough to prevent the consumption of silicate.

Since phytoplankton sensitivity to UV radiation varies among species and taxonomic groups, increases in surface UV-B radiation resulting from ozone depletion could induce changes in the phytoplankton community structure, as postulated by Jokiel \& York (1984), Karentz et al. (1991a), Vincent \& Roy (1993) and Santas et al. (1998). During this study, a shift from a community dominated by diatoms $(>10 \mu \mathrm{m})$ to a community dominated by small naked flagellates ( 5 to $10 \mu \mathrm{m}$ ) occurred more rapidly under enhanced UV-B than under natural UV-B radiation. This could have major implications for the transfer of carbon as the size of primary producers determines (1) the type and dynamics of trophic pathways and hence the number of trophic levels towards large metazoans and, (2) the rate of carbon fixation and its potential sequestration (e.g. Keller et al. 1997, Legendre \& Michaud 1998, Mostajir et al. 2000).

\section{Influence of UV-B on carbon transport rates}

An extensive literature describes the negative effects of UV-B radiation on photosynthesis (SteemanNielsen 1964, Lorenzen 1979, Smith et al. 1980, 1992 , Jokiel \& York 1984, Maske 1984, Helbling et al. 1992, Behrenfeld et al. 1993, Lesser et al. 1994, Villafañe et al. 1995, Figueroa et al. 1997). In this study, significant changes in phytoplankton productivity were observed throughout the experiment, of which some were associated with a UV-B induced alteration of the phytoplankton assemblage. The chl a specific carbon transport rate was lower during the last $2 \mathrm{~d}$ of the experiment, reflecting the lower photosynthetic performance of the phytoplankton assemblage at the end of the experiment (Fig. 5b). Although this reduction of photosynthetic performance may have resulted from an excess of irradiance or a nutrient limitation in the mesocosms on Days 6 and 7 , the lowest values were observed within the enhanced UV-B mesocosms and the highest within the WUV-B mesocosm. As shown by the relative chl $a$ specific carbon transport rate, the enhancement of UV-B was generally detrimental for photosynthesis while the reduction of UV-B was generally beneficial for photosynthesis (Fig. 5c). Low values of the relative chl a specific carbon transport rate appeared sooner in HUV-B than in LUV-B, suggesting that both the UV-B dose and the duration of exposure influence the carbon metabolism of the phytoplankton community

Although carbon productivity was generally highest in the WUV-B treatment, the chl a concentration was lower than in the other treatments during the last $2 \mathrm{~d}$ of the experiment (Figs. $2 \& 5 \mathbf{b}, \mathbf{c}$ ). Low algal biomass associated with high primary production per biomass unit may be indicative of a high grazing rate. In support of this hypothesis, Mostajir et al. (1999a) showed higher ciliate abundance $(15-35 \mu \mathrm{m})$ under reduced UV-B treatment compared to natural conditions during the last $2 \mathrm{~d}$ of this experiment. This, in turn, induced a decrease in the abundances of bacteria, heterotrophic flagellates $(2-10 \mu \mathrm{m})$ and small phytoplankton $(<5 \mu \mathrm{m})$ due to a higher grazing pressure exerted by the ciliates. Hence, the decrease in chl a may be explained by increased ciliate grazing on small photosynthetic algae. In contrast to the reduced UV-B treatment, a shift in the trophic structure from a herbivorous food web towards a microbial food web (bacteria, auto- and heterotrophic flagellates) occurred under enhanced UV-B (Mostajir et al. 1999a). Even within a microbial community, UV can alter the balance between autotrophic and heterotrophic processes (Bergeron \& Vincent 1997). Hence, changes in UV radiation may not only influence phytoplankton productivity and composition but also the fate of algal biomass.

In this study, the ratio of UV-B to total incident radiation was altered by the use of an artificial light source. The enhanced UV-B treatments received a higher proportion of UV-B radiation than the other treatments, especially during the cloudy period (Days 3 to 5) when incident irradiance was low. Variations in carbon and nitrogen transport rates were not correlated with these changes in the ratio of UV-B to total incident irradiance. These results contrast from those of Smith et al. (1992) who concluded that inhibition of photosynthesis increased linearly with the ratio of UV-B to total radiation. However, their study was conducted under different conditions in the marginal ice zone of the Bellingshausen Sea in the austral spring when the $\mathrm{O}_{3}$ layer was thinning. During their experiment, the vernal phytoplankton community was dominated by the prymnesiophyte Phaeocystis spp. while in our study, the summer algal community was composed of a mixed assemblage of diatoms, dinoflagellates and naked flagellates with different UV sensitivity. 
The potential short-term effect of UV-B radiation was estimated by sampling each treatment in the morning and in the afternoon. The carbon transport rate was often slightly higher in the afternoon than in the morning, despite the higher cumulative dose of UV received by the algae. This result indicates that phytoplankton has the ability to develop photoprotective mechanisms against UV irradiance on a daytime scale. Several adaptative strategies have been developed to protect the photosynthetic system from UV radiation (Karentz et al. 1994, Helbling et al. 1996a, Roy 2000). One of them is the synthesis of biological compounds which absorb in the UV wavelengths. Mycosporinelike amino acids (MAAs; Karentz et al. 1991b) and photoprotective pigments are examples of natural UV screens (Vincent \& Roy 1993). If their cellular concentrations increase under UV-B stress, photoprotection should be enhanced. In our study, enhanced UV-B induced both the synthesis of MAAs and an increase in total carotenoids relative to total chlorophylls from Days 4 to 7 (K. Walsh \& S.R. unpubl.) suggesting progressively increased photoprotection. However no clear trends were observed between morning and afternoon samples. Other photoprotective measures (e.g. DNA repair) may also be active, which could explain the differences observed here throughout the day.

\section{Influence of UV-B on total nitrogen uptake}

As with carbon, UV-B radiation is also known to negatively impact nitrogen transport in phytoplankton (Döhler et al. 1987, Döhler 1992, 1997, Behrenfeld et al. 1995, Lohmann et al. 1998). During our study, reduced and enhanced UV-B treatments generally influenced the chl $a$ specific transport rates of dissolved inorganic carbon and total dissolved nitrogen in approximately the same proportion, as compared to the natural conditions. Hence, the ratios of carbon to total nitrogen transport rates were not significantly affected by the different UV-B treatments. However, the ratio was generally higher than the 6.6 atomic ratio of Redfield et al. (1963) and varied significantly throughout the experiment. A part of this variability seems to be associated with changes in the incident irradiance. Indeed, this ratio was lower during the sunny days (at the beginning and at the end of the experiment) than during the cloudy days in the middle of the experiment. The variability of the ratio of carbon to total nitrogen transport rates may also be partly explained by major changes in the nitrogen sources (from nitrate to ammonium and urea; Fauchot et al. 2000) and the dominant algal groups (from diatoms to flagellates) which occurred during the study. The C:N transport ratio decreased during the 2 sunny day periods; during the first period (Days 1 and 2), a diatom-dominated community was actively using nitrate whereas during the second period (Days 6 and 7), a flagellate-dominated community was using mainly urea (Fauchot et al. 2000). Hence, the imbalance between $C$ and $N$ assimilation could be associated with changes in the incident irradiance, in the nitrogen sources and/or in the composition of the algal community.

As observed for the carbon to nitrogen assimilation ratio, the POC:PON ratio was also not strongly affected by the different UV-B treatments (Fig. $8 \mathrm{~b}$ ). This ratio was however higher than the Redfield atomic ratio (C:N = 6.6:1) during the last $2 \mathrm{~d}$ of the experiment, suggesting that the phytoplankton community was nutrient-limited. This increase in the POC:PON ratio may also be related to the resuspension of senescent cells from the earlier diatom bloom period (Days 1 to 3 ) due to the vertical mixing by the pump.

\section{CONCLUSIONS}

The results from this experiment show that enhanced UV-B radiation adversely affects the transport of carbon and nitrogen in phytoplankton when compared to reduced and natural UV-B. Since the rates of carbon and nitrogen uptake were affected in the same proportion by enhanced or reduced UV-B, very little differences in the $\mathrm{C}: \mathrm{N}$ transport ratio and POC:PON ratio were detected between treatments. Although UV-B radiation impaired phytoplankton, nighttime repair processes possibly took place since nitrogen transport rates did not decline throughout the study. Furthermore, photoprotective mechanisms seemed to develop during the day since afternoon carbon transport rates were slightly higher than morning ones. The enhanced and reduced UV-B treatments also modified the structure of the phytoplankton community. At the end of the experiment, the diatom $(>10 \mu \mathrm{m})$ abundance was lower under reduced and enhanced UV-B while abundances of dinoflagellates $(5-15 \mu \mathrm{m})$ and naked flagellates $(5-10 \mu \mathrm{m})$ were not affected by the UV-B treatments. The effect of UV-B on the phytoplankton community structure and their carbon and nitrogen transport rates may thus have broad implications for estuarine ecosystems and may seriously alter the transfer of matter within the pelagic food web.

Acknowledgements. This project was supported by grants from NSERC (Canada) to M.G., M.L., S.D. and S.R., Fonds FCAR (Québec) to M.G., M.L., S.D. and S.R. and FODAR (Fonds pour le développement et l'avancement de la recherche, Université du Québec) to M.G., S.D. and S.R., and by financial help from the Maurice Lamontagne Institute (Department of Fisheries and Oceans, Canada) provided to 
M.L. We thank C. Belzile, D. Bourget, G. Cantin and S. Doiron for field and laboratory assistance; N. Lafontaine and M.L. Dubé for nutrient analyses; W.G. Harrison for use of his mass spectrometer and L. Harris for performing the stable isotopes analyses; E. Bonneau and S. Lessard for their help in phytoplankton identification; E. Fouilland, A. Weise and 3 anonymous referees for useful comments on the manuscript. This is a contribution to the research programs of the Groupe de recherche en environnement côtier and of the Maurice Lamontagne Institute.

\section{LITERATURE CITED}

Behrenfeld MJ, Hardy J, Gucinski H, Hanneman A, Lee H ll, Wones A (1993) Effects of ultraviolet-B radiation on primary production along latitudinal transects in the South Pacific Ocean. Mar Environ Res 35:349-363

Behrenfeld MJ, Lee H Il, Small LF (1994) Interactions between nutritional status and long-term responses to ultraviolet- $B$ radiation stress in a marine diatom. Mar Biol 118:523-530

Behrenfeld MJ, Lean DRS, Lee H Il (1995) Ultraviolet-B radiation effects on inorganic nitrogen uptake by natural assemblages of oceanic plankton. J Phycol 31:25-36

Belzile C, Demers S, Lean DRS, Mostajir B, Roy S, de Mora S, Bird D, Gosselin M, Chanut JP, Levasseur M (1998) An experimental tool to study the effects of ultraviolet radiation on planktonic communities: a mesocosm approach. Environ Technol 19:667-682

Bergeron M, Vincent WF (1997) Microbial food web responses to phosphorus supply and solar UV radiation in a subarctic lake. Aquat Microb Ecol 12:239-249

Döhler G (1985) Effect of UV-B radiation $(290-320 \mathrm{~nm})$ on the nitrogen metabolism of several marine diatoms. J Plant Physiol 118:391-400

Döhler G (1989) Influence of UV-B (290-320 nm) radiation on photosynthetic ${ }^{14} \mathrm{CO}_{2}$ fixation of Thalassiosira rotula Meunier. Biochem Physiol Pflanz 185:221-226

Döhler G (1992) Impact of UV-B radiation on uptake of ${ }^{15} \mathrm{~N}$ ammonia and ${ }^{15} \mathrm{~N}$ nitrate by phytoplankton of the Wadden Sea. Mar Biol 112:485-489

Döhler G (1997) Effect of UVB radiation on utilization of inorganic nitrogen by Antarctic microalgae. Photochem Photobiol 66:831-836

Döhler G, Biermann 1 (1987) Effect of u.v.-B irradiance on the response of ${ }^{15} \mathrm{~N}$-nitrate uptake of Lauderia annulata and Synedra planctonica. J Plankton Res 9:881-890

Döhler G, Biermann T (1994) lmpact of UV-B radiation on the lipid and fatty acid composition of synchronized Ditylum brightwellii (West) Grunow. Z Naturforsch 49c:607-614

Döhler G, Buchmann T (1995) Effects of UV-A and UV-B irradiance on pigments and ${ }^{15} \mathrm{~N}$-ammonium assimilation on the haptophycean Pavlova. J Plant Physiol 146:29-34

Döhler G, Hagmeier E (1997) UV effects on pigments and assimilation of ${ }^{15} \mathrm{~N}$-ammonium and ${ }^{15} \mathrm{~N}$-nitrate by natural marine phytoplankton of the North Sea. Bot Acta 110: 481-488

Döhler G, Worrest RC, Biermann I, Zink J (1987) Photosynthetic ${ }^{14} \mathrm{CO}_{2}$ fixation and $\left[{ }^{15} \mathrm{~N}\right]$-ammonia assimilation during UV-B radiation of Lithodesmium variabile. Physiol Plant 70:511-515

Dugdale RC, Wilkerson FP (1986) The use of ${ }^{15} \mathrm{~N}$ to measure nitrogen uptake in eutrophic oceans; experimental considerations. Limnol Oceanogr 31:673-689

Falkowski PG, Stone DP (1975) Nitrate uptake in marine phytoplankton: energy sources and the interaction with carbon fixation. Mar Biol 32:77-84
Fauchot J, Gosselin M, Levasseur M, Mostajir B, Belzile C, Demers S, Roy S, Villegas PZ (2000) lnfluence of UV-B radiation on nitrogen utilization by a natural assemblage of phytoplankton. J Phycol 36 (in press)

Figueroa FL, Blanco JM, Jiménez-Gómez F, Rodriguez J (1997) Effects of ultraviolet radiation on carbon fixation in Antarctic nanophytoflagellates. Photochem Photobiol 66: 185-189

Fioletov VE, Evans WFJ (1997) The influence of ozone and others factor on surface radiation. In: Wardle Dl, Kerr JB, McElroy CT, Francis DR (eds) Ozone science: a Canadian perspective on the changing ozone layer. The University of Toronto Press, Toronto, p 73-90

Fioletov VE, Kerr JB, Wardle DI, Davies J, Hare EW, McElroy CT, Tarasick DW (1997) Long-term ozone decline over the Canadian Arctic to early 1997 from ground-based and balloon observations. Geophys Res Lett 24:2705-2708

Furgal JA, Smith REH (1997) Ultraviolet radiation and photosynthesis by Georgian Bay phytoplankton of varying nutrient and photoadaptive status. Can J Fish Aquat Sci 54:1659-1667

Furgal JA, Taylor WD, Smith REH (1998) Environmental control of photosynthate allocation in the phytoplankton of Georgian Bay (Lake Huron). Can J Fish Aquat Sci 55: 726-736

Goes JI, Handa N, Taguchi S, Hama T (1994) Effect of UV-B radiation on the fatty acid composition of a marine phytoplankter Tetraselmis sp.: relationship to pigments. Mar Ecol Prog Ser 114:259-274

Goes Jl, Handa N, Taguchi S, Hama T, Saito H (1995) lmpact of UV radiation on the production patterns and composition of dissolved free and combined amino acids in marine phytoplankton. J Plankton Res 17:1337-1362

Goes JI, Handa N, Taguchi S, Hama T, Saito H (1996) Metabolism of neutral monosaccharide constituents of storage and structural carbohydrates in natural assemblages of marine phytoplankton exposed to ultraviolet radiation. Limnol Oceanogr 41:1478-1489

Helbling EW, Villafañe VE, Ferrario $M$, Holm-Hansen $O$ (1992) Impact of natural ultraviolet radiation on rates of photosynthesis and on specific marine phytoplankton species. Mar Ecol Prog Ser 80:89-100

Helbling EW, Chalker BE, Dunlap WC, Holm-Hansen O, Villafañe VE (1996a) Photoacclimation of Antarctic marine diatoms to solar ultraviolet radiation. J Exp Mar Biol Ecol 204:85-101

Helbling EW, Eilertsen HC, Villafañe VE, Holm-Hansen $O$ (1996b) Effects of UV radiation on post-bloom phytoplankton populations in Kvalsund, North Norway. Photochem Photobiol 33:255-259

Jokiel PL, York RHJ (1984) lmportance of ultraviolet radiation in photoinhibition of microalgal growth. Limnol Oceanogr 29:192-199

Karentz D, Cleaver JE, Mitchell DL (1991a) Cell survival characteristics and molecular responses of Antarctic phytoplankton to ultraviolet-B radiation. J Phycol 27:326-341

Karentz D, McEuen FS, Land MC, Dunlap WC (1991b) Survey of mycosporine-like amino acid compounds in Antarctic marine organisms: potential protection from ultraviolet exposure. Mar Biol 108:157-166

Karentz D, Bothwell ML, Coffin RB, Hanson A, Herndl GJ, Kilham SS, Lesser MP, Lindell M, Moeller RE, Morris DP, Neale PJ, Sanders RW, Weiler CS, Wetzel RG (1994) lmpact of UV-B radiation on pelagic freshwater ecosystems: report of working group on bacteria and phytoplankton. Arch Hydrobiol Beih Ergebn Limnol 43:31-69

Keller AA, Hargrave P, Jeon H, Klein-MacPhee G, Klos E, Oviatt C, Zhang J (1997) Effects of ultraviolet-B enhance- 
ment on marine trophic levels in a stratified coastal system. Mar Biol 130:277-287

Kerr JB, McElroy CT (1993) Evidence for large upward trends of ultraviolet-B radiation linked to ozone depletion. Science 262:1032-1034

Kirk JTO, Hargreaves BR, Morris DP, Coffin RB, David B, Frederickson D, Karentz D, Lean DRS, Lesser MP, Modronich S, Morrow JH, Nelson NB, Scully NM (1994) Measurements of UV-B radiation in 2 freshwater lakes: an instrument intercomparison. Arch Hydrobiol Beih Ergebn Limnol 43:71-99

Legendre L, Michaud J (1998) Flux of biogenic carbon in oceans: size-dependent regulation by pelagic food webs. Mar Ecol Prog Ser 164:1-11

Lesser MP, Cullen JJ, Neale PJ (1994) Carbon uptake in a marine diatom during acute exposure to ultraviolet $B$ radiation: a relative importance of damage and repair. J Phycol 30:183-192

Levasseur M, Therriault JC, Legendre L (1984) Hierarchical control of phytoplankton succession by physical factors. Mar Ecol Prog Ser 19:211-222

Lohmann M, Döhler G, Huckenbeck N, Verdini S (1998) Effects of UV radiation of different wavebands on pigmentation, ${ }^{15} \mathrm{~N}$-ammonium uptake, amino acid pools and adenylate contents of marine diatoms. Mar Biol 130: 501-507

Lorenzen CJ (1979) Ultraviolet radiation and phytoplankton photosynthesis. Limnol Oceanogr 24:1117-1120

Lund JWG, Kipling C, Le Cren ED (1958) The inverted microscope method of estimating algal numbers and the statistical basis of estimations by counting. Hydrobiologia 11: $144-170$

Maske $H$ (1984) Daylight ultraviolet radiation and the photoinhibition of phytoplankton carbon uptake. J Plankton Res 6:351-357

McQueen DJ, Post DJ, Mills RJ (1986) Trophic relationships in freshwater pelagic ecosystems. Can J Fish Aquat Sci 43: $1571-1581$

Melis A, Nemson JA, Harrison MA (1992) Damage to functional components and partial degradation of photosystem II reaction center proteins upon chloroplast exposure to ultraviolet-B radiation. Biochim Biophys Acta 1100 312-320

Mostajir B, Demers $S$, de Mora S, Belzile $C$, Chanut JP, Gosselin M, Roy S, Villegas PZ, Fauchot J, Bouchard JN, Bird D, Monfort P, Levasseur M (1999a) Experimental test of the effect of ultraviolet-B radiation in a planktonic community. Limnol Oceanogr 44:586-596

Mostajir B, Sime-Ngando T, Demers S, Belzile C, Roy S, Gosselin M, Chanut JP, de Mora S, Fauchot F, Vidussi F, Levasseur M (1999b) Ecological implications of changes in cell size and photosynthetic capacity of marine Prymnesiophyceae induced by ultraviolet-B radiation. Mar Ecol Prog Ser 187:89-100

Mostajir B, Demers S, de Mora SJ, Bukata RP, Jerome JH (2000) Implications of UV radiation on the food web structure and consequences on the carbon flow. In: de Mora SJ, Demers $S$, Vernet $M$ (eds) The effects of UV radiation in the marine environment. Cambridge University Press, Cambridge, p 310-320

Nilawati J, Greenberg BM, Smith REH (1997) Influence of ultraviolet radiation on growth and photosynthesis of two cold ocean diatoms. J Phycol 33:215-224

Nozais C, Desrosiers G, Gosselin M, Belzile C, Demers S (1999) Effects of ambient UVB radiation in a meiobenthic community of a tidal mudflat. Mar Ecol Prog Ser 189: 149-158

Parsons TR, Maita Y, Lalli CM (1984) A manual of chemical and biological methods for seawater analysis. Pergamon Press, Oxford

Price NM, Harrison PJ (1987) A comparison of methods for the analysis of dissolved urea concentrations in seawater. Mar Biol 94:307-317

Redfield AC, Ketchum BH, Richards FA (1963) The influence of organisms on the composition of sea-water. ln: Hill MN (ed) The sea, Vol 2. Interscience, New York, p 26-77

Rex M, Harris NRP, Von der Gathen P, Lehman R, Braathen GO, Reimer E, Beck A, Chipperfield MP, Alfier R, Allaart M, O'Connor F, Dier H, Dorokhov V, Fast H, Gil M, Kyrö E, Litynska Z, Mikkelsen IS, Molyneux MG, Nakane H, Notholt J, Rummukainen M, Viatte P, Wenger J (1997) Prolonged stratospheric ozone loss in the 1995-96 Arctic winter. Nature 389:835-838

Roy S (2000) Strategies for the minimization of UV-induced damage. In: de Mora SJ, Demers $S$, Vernet $M$ (eds) The effects of UV radiation in the marine environment. Cambridge University Press, Cambridge, p 177-205

Roy S, Chanut JP, Gosselin M, Sime-Ngando T (1996) Characterization of phytoplankton communities in the Lower St. Lawrence Estuary using HPLC-detected pigments and cell microscopy. Mar Ecol Prog Ser 142:55-73

Santas R, Santas Ph, Lianou C, Korda A (1998) Community response to UV radiation. 1l. Effects of solar UVB on fieldgrown diatom assemblages of the Caribbean. Mar Biol 131:163-171

Schofield O, Kroon BMA, Prézelin BB (1995) lmpact of ultraviolet-B radiation on photosystem 11 activity and its relationship to the inhibition of carbon fixation rates for Antarctic ice algae communities. J Phycol 31:703-715

Sime-Ngando T, Gosselin M, Roy S, Chanut JP (1995) Significance of planktonic ciliated protozoa in the Lower St. Lawrence Estuary: comparison with bacterial, phytoplankton, and particulate organic carbon. Aquat Microb Ecol 9:243-258

Smith RC, Baker KS, Holm-Hansen O, Olson R (1980) Photoinhibition of photosynthesis in natural waters. Photochem Photobiol 31:585-592

Smith RC, Prézelin BB, Baker KS, Bidigare RR, Boucher NP, Coley T, Karentz D, Maclntyre S, Matlick HA, Menzies D Ondrusek M, Wan Z, Waters KJ (1992) Ozone depletion: ultraviolet radiation and phytoplankton biology in Antarctic waters. Science 255:952-959

Smith REH, Furgal JA, Lean DRS (1998). The short-term effects of solar ultraviolet radiation on phytoplankton photosynthesis and photosynthate allocation under contrasting mixing regimes in Lake Ontario. J Gt Lakes Res 24: $427-441$

Solórzano L (1969) Determination of ammonia in natural waters by the phenolhypochlorite method. Limnol Oceanogr 14: 799-801

Steeman-Nielsen E (1964) On a complication in marine productivity work due to the influence of ultraviolet light. J Cons Perm Int Explor Mer 29:130-135

Tarasick DW, Fioletov VE (1997) The distribution of ozone and ozone-depleting substances in the atmosphere and observed changes. In: Wardle DI, Kerr JB, McElroy CT, Francis DR (eds) Ozone science: a Canadian perspective on the changing ozone layer. The University of Toronto Press, Toronto, p 15-40

Throndsen J (1978) Preservation and storage. ln: Sournia A (ed) Phytoplankton manual. The UNESCO Press, Paris, p 69-74

Turpin DH, Bruce D (1990) Regulation of photosynthetic light harvesting by nitrogen assimilation in the green alga Selenastrum minutum. FEBS Lett 263:99-103 
Villafañe VE, Helbling EW, Holm-Hansen O, Chalker BE (1995) Acclimatization of Antarctic natural phytoplankton asemblages when exposed to solar ultraviolet radiation. J Plankton Res 17:2295-2306

Villegas PZ (1999) Effets du rayonnement solaire ultraviolet de type B sur une communauté phytoplanctonique de l'estuaire maritime du Saint-Laurent. Masters thesis, Université du Québec à Rimouski

Editorial responsibility: Otto Kinne (Editor),

Oldendorf/Luhe, Germany
Vincent W, Roy S (1993) Solar ultraviolet-B radiation and aquatic primary production: damage, protection, and recovery. Environ Rev 1:1-12

Vosjan JH, Döhler G, Nieuwland G (1990) Effect of UV-B irradiance on the ATP content of microorganisms of the Weddell Sea (Antarctica). Neth J Sea Res 25:391-393

Zar JH (1984) Biostatistical analysis. Prentice-Hall, Englewood Cliffs, NJ

Submitted: May 17, 1999; Accepted: January 27, 2000

Proofs received from author(s): May 26, 2000 